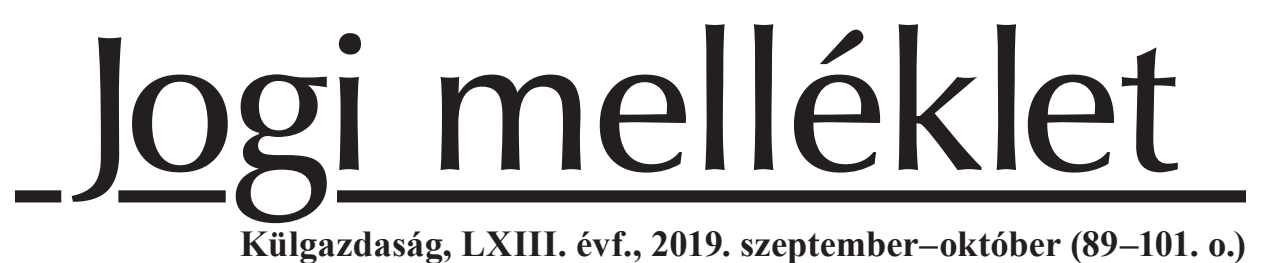

\title{
Az Európai Bíróság CETA-véleménye és a beruházásvédelmi bíráskodás jövője SZABADOS TAMÁS
}

Az Európai Unió Bírósága 1/17. számú véleményében arra a következtetésre jutott, hogy a Kanada és az Európai Unió (EU, Unió) között létrejött átfogó gazdasági és kereskedelmi megállapodásban (CETA) foglalt beruházási jogviták rendezésére létrehozott mechanizmus nem ütközik az uniós jogba. Az Európai Bíróság által adott megerösités azért lényeges, mert a CETA szabályai modellként szolgálhatnak az Unió által a későbbiekben megkötendö, beruházásvédelmi szabályokat is tartalmazó megállapodások, valamint a tervezett multilaterális beruházási biróság számára is. Ugyanakkor a CETA szabályainak elemzése felvet bizonyos kételyeket, mivel úgy tünik, a vitarendezési eljárás egyes elöirásai - az Európai Bíróság álláspontja ellenére - kihatással lehetnek az uniós jogrend autonómiájára.

Journal of Economic Literature (JEL) kód: K33.

\section{A CETA és a beruházási viták rendezése}

A Kanada és az Európai Unió (EU, Unió) között létrejött átfogó gazdasági és kereskedelmi megállapodás (Comprehensive Economic and Trade Agreement, CETA) az új generációs szabadkereskedelmi megállapodások közé tartozik, mivel a szabadkereskedelmi egyezmények hagyományos tárgyán, a vámok és nem vámjellegü akadályok lebontásán túl, egyebek között, előírásokat tartalmaz az állami támoga-

https://doi.org/10.47630/KULG.2019.63.9-10.89

Szabados Tamás, habilitált egyetemi docens, ELTE Állam- és Jogtudományi Kar, Nemzetközi Magánjogi és Európai Gazdasági Jogi Tanszék. E-mail: szabados@ajk.elte.hu 
tásokra, a beruházásokra, a versenykorlátozó magatartásokra, a közbeszerzésekre, valamint a szellemi tulajdon védelmére.

Az Európai Unió Tanácsának (Tanács) 2017/37 határozata felhatalmazást adott a CETA-nak az Unió nevében történő aláírására, ${ }^{1}$ amelyre 2016. október 30-án Brüszszelben került sor. A 2017/38 tanácsi határozat pedig a CETA szabályai jelentős részének 2017. szeptember 21-én történő ideiglenes hatálybalépéséről rendelkezett. ${ }^{2}$ A megállapodás teljes hatálybalépéséhez szükség van annak megerősítésére valamennyi tagállamban, amely megkívánja a nemzeti - és egyes államokban a regionális - parlamentek jóváhagyását.

A CETA egy sajátos mechanizmust hoz létre a beruházásokkal kapcsolatos jogviták rendezésére. Ennek előképe már megjelent az EU javaslatában a transzatlanti kereskedelmi és befektetési partnerségről (TTIP) szóló, az Egyesült Államokkal folytatott tárgyalások során, ${ }^{3}$ valamint hasonló szabályok találhatók az EU és Vietnám között létrejött szabadkereskedelmi egyezményhez kapcsolódó beruházásvédelmi egyezményben is. ${ }^{4}$ Ugyanakkor, miután az Európai Unió Bírósága (Európai Bíróság) 1/09. számú véleményével a szabadalmi jogviták rendezésére szolgáló egységes rendszert összeegyeztethetetlennek találta az uniós joggal, ${ }^{5}$ majd Achmea-ítéletével a beruházásvédelem kontextusában a tagállamok közötti beruházásvédelmi egyezményekben szereplő választottbírósági klauzulákat minősítette ellentétesnek az Unió jogával, ${ }^{6}$ felmerült a kérdés, vajon a CETA beruházásokra vonatkozó vitarendezési szabályai összhangban állnak-e az uniós joggal.

Belgiumban, bár a szövetségi kormány támogatta a CETA-t, a vallon kormányzat tiltakozott elfogadása ellen, mindenekelőtt éppen a CETA-ba épített vitarendezési mechanizmus miatt, amely lehetővé teszi a befektetők számára, hogy a részes felek, így a tagállamok és az EU ellen eljárást indítsanak az egyezményben foglalt jogaik sérelme esetén, a vallon kormány érvelése szerint, kétségbe vonva a belga és

1 A Tanács (EU) 2017/37 határozata (2016. október 28.) az egyrészről Kanada, másrészről az Európai Unió és tagállamai közötti átfogó gazdasági és kereskedelmi megállapodás (CETA) Európai Unió nevében történő aláírásáról, HL L 11, 14.1.2017, 1-2. o.

2 A Tanács (EU) 2017/38 határozata (2016. október 28.) az egyrészről Kanada, másrészről az Európai Unió és tagállamai közötti átfogó gazdasági és kereskedelmi megállapodás (CETA) ideiglenes alkalmazásáról, HL L 11., 2017.1.14., 1080-1081. o.

3 European Union's proposal for Investment Protection and Resolution of Investment Disputes. Letöltés: https://trade.ec.europa.eu/doclib/docs/2015/november/tradoc_153955.pdf. Horváthy [2016], 83-97. o.

${ }^{4}$ EU-Vietnam Investment Protection Agreement, Section B.

5 1/09. sz. vélemény [EBHT 2011., I-1137. o.].

${ }^{6}$ C-284/16. sz. Szlovák Köztársaság kontra Achmea BV ügy, ECLI:EU:C:2018:158; Szabados [2019], 29-36. o. 
uniós szabályozást.? Az egyezmény szövetségi kormány általi aláírásához szükség volt a régiók felhatalmazására. Vegyes nemzetközi szerződésről lévén szó, amelynek felei Kanada mellett az EU és szintúgy a tagállamok, a belga ratifikáció nélkül nem léphetett volna hatályba a CETA. Végül a belga szövetségi kormányzat és Vallónia között az a kompromisszumos megoldás született, hogy a szövetségi kormány kikéri az Európai Bíróság véleményét a vitarendezési szabályok uniós joggal való összeegyeztethetőségéről. Erre az Európai Unió működéséről szóló szerződés (EUMSz) 218. cikk (11) bekezdése alapján került sor, ${ }^{8}$ amely megengedi, hogy egy tagállam az Európai Bíróság véleményét kérje valamely tervezett megállapodásnak a Szerződésekkel való összeegyeztethetőségéről. A Belga Királyság azt a kérdést vetette fel, hogy a megállapodás „Beruházás” címet viselő nyolcadik fejezetének F szakasza, amelynek tárgya „A beruházó és az állam közötti, beruházásokkal kapcsolatos viták rendezése", ellentétben áll-e az uniós jog autonómiájával, az egyenlő bánásmód követelményével, az uniós jog tényleges érvényesülésének elvével, valamint a független és pártatlan bírósághoz fordulás jogával. Megjegyzendő, hogy éppen a beruházási jogviták rendezésére vonatkozó szabályok kivételt képezve nem kerülnek ideiglenesen alkalmazásra a részes felek által. A vélemény kérése a CETA szempontjából azért volt lényeges, mert ha az Európai Bíróság véleménye kedvezőtlen lett volna, a tervezett megállapodás csak akkor léphetett volna hatályba, ha azt módosítják.

A CETA beruházásokkal kapcsolatos szabályai az egyik fél beruházója és a másik fél közötti jogviták eldöntésére létrehozzák a Fórumot, amely előtt a beruházó keresetet indíthat, amennyiben úgy ítéli meg, hogy a másik fél megsértette a CETA nyolcadik fejezetének C, illetve D szakaszában foglalt kötelezettségeit, amelyek olyan tipikus beruházásvédelmi sztenderdeket írnak elő, mint a megkülönböztetésmentes elbánás, a tisztességes és méltányos elbánás, a teljes körü védelem és biztonság, a kisajátítás elleni védelem, továbbá az átutalások szabadsága. A CETA vitarendezési mechanizmusa jelentős újdonságokat tartalmaz. Először is a befektetők, valamint az EU, illetve a tagállamok vagy Kanada közötti jogvitákat a beruházásvédelmi jogban hagyományosan alkalmazott választottbíróság helyett az állandó tagsággal rendelkező Fórum rotációs rendszerben, véletlenszerủen kijelölt háromtagú tanácsa bírálja el, ami kizárja a jogvitában érdekelt felek ráhatását az eljáró tanács összetételére. A Fórum tizenöt tagból áll, akiket a megállapodás végrehajtásáért és alkalmazásáért felelős CETA Vegyes Bizottság nevez ki öt évre azzal, hogy a kine-

7 Ankersmit [2016], 54. o.

${ }^{8}$ Az Európai Unió múködéséről szóló szerződés egységes szerkezetbe foglalt változata, HL C 326., 2012.10.26., 47-390. o. 
vezés egyszer megújítható. Öt tag EU-tagállam állampolgára, öt tag Kanada állampolgára és öt tag harmadik ország állampolgára. A Fórum tagjai olyan személyek lehetnek, akik megfelelnek a saját államuk bírói kinevezéshez elöírt feltételeinek, vagy egyébként elismert szakértelemmel rendelkező jogászok, és tapasztalattal rendelkeznek a nemzetközi közjog területén, különösen a nemzetközi beruházási jog, a nemzetközi kereskedelmi jog és a nemzetközi beruházásokkal vagy nemzetközi kereskedelmi megállapodásokkal kapcsolatban felmerült viták rendezése területén. Az ügyeket tárgyaló háromtagú tanácsok egy-egy uniós és kanadai taggal és a harmadik országbeli tag elnökletével végzik tevékenységüket. Ugyanakkor a felek megállapodhatnak abban is, hogy ügyüket a Fórum valamely véletlenszerüen kijelölt, harmadik állambeli tagja egyedül bírálja el. A Fórum a marasztalt felet kártérítés megfizetésére, illetve kisajátítás esetében a tulajdonjog visszaállítására, vagy e helyett kártalanítás fizetésére kötelezheti. A rendszer másik újdonsága, hogy a felek a döntés felülvizsgálatát a Fellebbviteli Fórumtól kérhetik, méghozzá tágabb körben, mint ahogy arra az ICSID-egyezmény alapján lehetőség van, ${ }^{9}$ illetve annál, ahogy a nemzeti jogok általában megengedik a választottbírósági határozatok érvénytelenítését. Az ICSID-egyezményben nevesített hatályon kívül helyezési indokok mellett a Fellebbviteli Fórum módosíthatja vagy hatályon kívül helyezheti a Fórum ítéletét az alkalmazandó jogszabályok hibás alkalmazása vagy értelmezése esetén, valamint akkor, ha nyilvánvaló hiba történt a tények mérlegelésében, ideértve a vonatkozó hazai jogszabályok mérlegelését is. A Fellebbviteli Fórum müködésével kapcsolatos szervezési és adminisztratív kérdésekről, különösen annak összetételéről a CETA Vegyes Bizottság határoz, de az ugyancsak véletlenszerüen kinevezett háromtagú tanácsban járhat el és a Fellebbviteli Fórum tagjainak a Fórum tagjaitól is megkívánt képesítéssel és szakértelemmel kell rendelkeznie. A CETA előirányozza azt is, hogy a fent vázolt vitarendezési mechanizmust a jövőben felválthatja egy beruházási vitákkal foglalkozó multilaterális igazságszolgáltatási rendszer.

\section{Az Európai Bíróság 1/17. számú véleménye}

Az Európai Bíróság 1/17. számú véleményében arra a következtetésre jutott, hogy a CETA által bevezetett beruházásokkal kapcsolatos vitarendezési mechaniz-

9 1987. évi 27. törvényerejü rendelet az Államok és más államok természetes és jogi személyei közötti beruházási viták rendezéséről szóló, Washingtonban, 1965. március 18-án kelt Egyezmény kihirdetéséröl, 52. cikk (1) bekezdés. 
mus nem ütközik az uniós jogba. Elöször is a megállapodás nem sérti az uniós jog autonómiáját. Az Unió hatásköre a nemzetközi kapcsolatok terén kiterjed arra, hogy nemzetközi megállapodással - a megállapodás értelmezése és alkalmazása céljából - nemzetközi bíróság létrehozásában vegyen részt, illetve az így létrehozott bíróság határozatainak alávesse magát, feltéve hogy a bíróság létrejötte és müködése nem sérti az uniós jog autonómiáját, ideértve az Európai Bíróság hatáskörét az uniós jog végső soron történő értelmezésére. Bár a CETA-ban foglalt vitarendezési mechanizmus az uniós bírósági rendszeren kívül áll, a vélemény szerint az mégsem sérti az uniós jogrendszer autonómiáját, mivel egyrészről a létrehozott fórumok nem bírnak hatáskörrel arra, hogy értelmezzék és alkalmazzák az uniós jogot, másrészről nem hozhatnak olyan ítéleteket, amelyek meggátolnák az uniós intézményeket abban, hogy az Unió alkotmányos keretének megfelelően müködjenek.

A CETA fórumai kizárólag arra rendelkeznek hatáskörrel, hogy a CETA elöírásait értelmezzék és alkalmazzák. A CETA kifejezetten rögzíti, hogy a Fórumnak nincsen joghatósága arra, hogy elbírálja, hogy egy, állítólagosan a CETA-ba ütköző intézkedés egyúttal sérti-e valamely fél hazai jogát, ideértve az uniós jogot is. Ugyanez áll a Fellebbviteli Fórumra is. Annak eldöntése céljából, hogy valamely intézkedés összhangban áll-e a CETA rendelkezéseivel, a Fórum csupán tényként veheti figyelembe a fél hazai jogát, tehát az uniós jogot is. Ennek során pedig a Fórum köteles követni a fél bíróságainak és hatóságainak a hazai jogra vonatkozó értelmezését. E bíróságokra és hatóságokra pedig nem kötelező a belső jognak a Fórum által adott értelmezése. Az Európai Bíróság itt hangsúlyozta a CETA rendelkezéseinek különbözőségét a szabadalmi jogviták rendszeréhez és a beruházásvédelmi választottbíráskodáshoz képest. A tervezett szabadalmi bíróság hatáskörrel bírt volna uniós jogszabályok alkalmazására, ahogy az Achmea-ítéletben érintett beruházásvédelmi választottbírósági eljárásokban is felmerülhetett esetlegesen az uniós jog értelmezése és alkalmazása. Az Achmea-döntés ráadásul a tagállamok között létrejött kétoldalú beruházásvédelmi megállapodásokban foglalt választottbírósági klauzulák alkalmazását zárta ki, míg a CETA esetében egy az Unió és egy harmadik állam közötti megállapodás létesíti a bíróságot, ahol szemben a tagállamok egymás közötti viszonyával nem érvényesül a kölcsönös bizalom elve. Tekintettel arra, hogy a Fórum és a Fellebbviteli Fórum az uniós bírósági rendszeren kívül helyezkednek el és nincsen hatáskörük az uniós jog alkalmazására, nem veszélyeztetheti az uniós jogrend autonómiáját az sem, hogy nem fordulhatnak elözetes döntéshozatali kérelemmel az Európai Bírósághoz és nem adott a Fórum vagy 
a Fellebbviteli Fórum határozatával szemben az Európai Bíróság vagy a beruházás szerinti ország bírósága előtt a felülvizsgálat lehetősége.

A CETA vitarendezési mechanizmusa nem akadályozza az uniós intézményeket abban, hogy az Unió alkotmányos keretének megfelelően müködjenek, mivel a CETA elismeri annak lehetőségét, hogy az Unió a közrend, a közbiztonság, a közerkölcs, az emberek és állatok egészségének vagy életének, az élelmiszer-biztonság, a növények, a környezet, a munkahelyi jóllét, a termékbiztonság, a fogyasztók vagy az alapvető jogok védelme érdekében szükséges intézkedéseket fogadjon el, és a CETA fórumok valamely fél demokratikusan meghozott ilyen döntését nem vitathatják.

Másodszor, az Európai Bíróság megállapította, hogy a tervezett vitarendezési mechanizmus nem ellentétes az egyenlő bánásmód, valamint az uniós jog tényleges érvényesülésének követelményével. Az Alapjogi Charta 21. cikk (2) bekezdése, ${ }^{10}$ amely tiltja az állampolgárság alapján történő minden megkülönböztetést - az EUMSz. 18. cikkel összhangban értelmezve -, csak az uniós polgárok közötti megkülönböztetést tiltja, vagyis nem terjed ki az uniós és kanadai beruházók esetleg eltérő kezelésére. Vizsgálandó volt ugyanakkor a törvény elötti egyenlőség követelménye, amely ilyen korlátozás nélkül alkalmazandó. Nem valósít meg eltérő bánásmódot az, hogy kizárólag kanadai befektetők vitathatják az Unió intézkedéseit a CETAfórum előtt, míg a tagállami befektetőknek erre nincsen lehetőségük, mivel az Unió területén beruházó kanadai befektetők nincsenek összehasonlítható helyzetben az Unióban beruházó tagállami vállalkozásokkal és természetes személyekkel. Nem állapította meg az Európai Bíróság az uniós versenyjog tényleges érvényesülésének sérelmét sem, arra tekintettel, hogy a CETA Fórum olyan ítéletet hozhat, amelyben megállapítja, hogy valamely kanadai befektetővel szemben az Európai Bizottság (Bizottság) vagy tagállami versenyhatóság által a versenyjogi szabályok megsértése miatt kiszabott bírság a CETA rendelkezéseibe ütközik, mivel ez csak akkor merülhet fel, ha a Bizottság vagy a tagállami versenyhatóság nem szabályszerűen alkalmazza a versenyszabályokat (megsértve a tisztességes és méltányos elbánás követelményét vagy kisajátítást eredményezve), ilyen esetben pedig maga az uniós jog is lehetővé teszi az olyan, a versenyjogi szabályok megsértése miatt kiszabott bírság törlését, amennyiben a bírság kiszabása nem volt jogszerü.

Harmadszor, a tervezett vitarendezési rendszer nem sérti a független bírósághoz való fordulás jogát sem. A természetes személy, valamint kis- és középvállalkozás befektetők esetén sem sérül az igazságszolgáltatáshoz való hozzáférés követelmé-

10 Az Európai Unió Alapjogi Chartája, HL C 202., 2016.6.7., 389-405. o. 
nye, mivel a Bizottság és a Tanács nyilatkozattal vállalta azt, hogy valamennyi uniós befektető számára biztosítja a fórumokhoz való hozzáférést, és ez a CETA Unió általi jóváhagyásának feltétele. A tervezett megállapodás nem ütközik a függetlenség követelményébe sem, megfelel annak mind külső (a feladatkör autonóm módon történő gyakorlása minden alárendeltség, külső nyomás vagy beavatkozás nélkül), mind belső összetevőjének (egyenlő távolság tartása a jogvitában részt vevő felektől). A fórumok külső függetlenségét azon szabályok biztosítják, amelyek elöírják, hogy a fórumok teljesen önállóan látják el a feladataikat, tagjaikat határozott időtartamra nevezik ki és szakértelemmel kell rendelkezniük. A tagok megfelelő javadalmazásra jogosultak és elmozdíthatatlanok. A belső függetlenséget az irányadó összeférhetetlenségi és etikai szabályok garantálják, így az, hogy a tagok nem állhatnak kapcsolatban egyetlen kormánnyal sem, illetve hogy nem kaphatnak utasításokat feladataik ellátása során. Ugyanezt biztosítja az is, hogy az ügyeket előre nem kiszámítható módon, véletlenszerüen kijelölt háromtagú tanács bírálja el egy harmadik állam állampolgárának elnökletével az uniós és a kanadai tag mellett.

\section{A vélemény elfogadását követő kérdések}

Az Európai Bíróság által adott véleménynek az uniós jogrend autonómiájával kapcsolatos része bizonyos kétségeket ébreszt. Kérdések merülnek fel az Európai Bíróság mindkét vizsgálati szempontja vonatkozásában, tehát a tekintetben, hogy a CETA fórumai egyrészt nem alkalmazhatják, illetve értelmezhetik az Unió jogát, másrészről, hogy a CETA hatásköri szabályai nem akadályozhatják az uniós intézményeket abban, hogy az Unió alkotmányos keretének megfelelően működjenek.

Ami az uniós jogrend autonómiáját illeti, kérdés, hogy mennyiben választható élesen ketté valamely jog alkalmazása és ténybeli körülményként történő figyelembevétele. Az uniós nemzetközi magánjog kontextusában az Európai Bíróság Nikiforidis-ítéletében megkülönböztette ezt a két eljárást, bár ott nem az uniós jog, hanem a nemzeti jog ténybeli körülményként való figyelembevételéről volt szó. ${ }^{11} \mathrm{~A}$ kollíziós jogban a megkülönböztetés azért fontos, mert az anyagi jog szintjén ténybeli körülményként lehet figyelembe venni olyan külföldi imperatív normákat, amelyek nem képezik vagy képezhetik részét az alkalmazandó jognak, mert nem részei a lex causae-nak, vagy mert például a fórum joga kizárja a külföldi közjogi szabályok

${ }^{11}$ C-135/15. sz. Görög Köztársaság kontra Grigorios Nikiforidis ügy, ECLI:EU:C:2016:774. 
alkalmazását. Érdekes módon a beruházásvédelem területén az Európai Bíróság ezt a megkülönböztetést éppen a választottbírósági gyakorlatból vehette át, ahol több, az uniós jog és a kétoldalú beruházásvédelmi egyezmény viszonyát felvető ügyben az uniós jogot az állami joggal együtt ténynek tekintették. ${ }^{12}$ Érdekes módon az Eureko(a későbbi Achmea-) ügyben maga a választottbíróság is leszögezte, hogy hatásköre csak a kétoldalú beruházásvédelmi egyezmény megsértésének megállapítására korlátozódik, de az nem terjed ki arra, hogy az uniós jog megsértését megállapítsa. ${ }^{13}$ Wathelet fötanácsnok erre visszautalva úgy fogalmazott, hogy az uniós jog az egyik olyan releváns tényező, amelyet az adott állam a BIT tekintetében tanúsított magatartásának értékelése során figyelembe kell venni. ${ }^{14}$ Ott az alkalmazandó jog és a releváns tény megkülönböztetését nem fogadta el az Európai Bíróság, de az 1/17. számú véleményében, a harmadik államokkal való kapcsolatra nézve ugyanezt már éppen az Európai Bíróság használja fel.

Minden erre irányuló törekvés ellenére a CETA szövege sem tudja kizárni teljesen egyértelműen az uniós jog CETA Fórum és a CETA Fellebbviteli Fórum általi értelmezését a hazai jog részeként. A 8.31 cikk (2) bekezdése arra utal, hogy amikor a Fórum tényként veszi figyelembe a fél hazai jogát, akkor ,a Fórum követi a hazai jognak az adott Fél bíróságai vagy hatóságai általi értelmezését”. Bár ez a rendelkezés minden mozgásteret el kíván venni a CETA Fórumtól, hogy ne kelljen értelmeznie a fél hazai jogát, az mégsem kerülhető el minden esetben. Elképzelhető ugyanis, hogy az uniós jog valamely szabályát még nem volt alkalma értelmezni az Európai Bíróságnak vagy akár a tagállami bíróságoknak. ${ }^{15} \mathrm{Az}$ sem zárható ki, hogy ellentétes értelmezések kapcsolódjanak valamilyen szabályhoz anélkül, hogy meg lehessen állapítani, hogy mi az uralkodó álláspont. Ráadásul nem mindig a domináns álláspont a helyes, és az sem bizonyos, hogy az Európai Bíróság később ezt erősíti meg. Az uniós jog értelmezését még az Európai Bírósági döntése sem merevíti meg teljesen. Az uniós jog valamely szabályával összefüggésben az Európai Bíróság által adott értelmezés nem köti az Európai Bíróságot, attól a későbbiekben eltérhet. ${ }^{16}$ A CETA 8.28 cikk (2) bekezdése alapján a Fellebbviteli Fórum módosíthatja vagy hatályon kívül helyezheti a Fórum ítéletét akkor, ha nyilvánvaló hiba történt a té-

12 Lásd például AES Summit Generation Limited and AES-Tisza Erömü Kft v. The Republic of Hungary, ICSID Case No. ARB/07/22, Award, 2010. szeptember 23., 7.6.6. pont.

${ }_{13}$ Eureko B.V.v. The Slovak Republic, Award on Jurisdiction, Arbitrability and Suspension, UNCITRAL, PCA Case No. 2008-13, 2010. október 26., 290. pont.

14 C-284/16. sz. Szlovák Köztársaság kontra Achmea BV ügy, Melchior Wathelet fötanácsnok indítványa ECLI:EU:C:2017: 699, 175. pont.

15 Ankersmit [2017], 22. o; Gatti [2019], 117-118. o.

16 Szabados [2015], 130. o; Ankersmit [2017], 22. o. 
nyek mérlegelésében, ideértve a hazai jog szabályainak mérlegelését is. Bár a szöveg „mérlegelésre” utal, ha a jog „mérlegelése” eltér a Fórum és a Fellebbviteli Fórum által, akkor az abból fakadhat, hogy azt eltérően értelmezték. ${ }^{17}$ A 8.31 cikk (2) bekezdése alapján a hazai jognak a Fórum általi értelmezése nem kötelező az érintett Fél bíróságaira vagy hatóságaira nézve. A CETA magyar szövege kifejezetten elismeri, hogy itt értelmezésről van szó, csak éppen nem kötelező erővel bíró értelmezésről. Bár az angol nyelvủ szöveg a Fórum által a hazai jognak tulajdonított jelentésről beszél (,, any meaning given to domestic law by the Tribunal”), a német nyelvi változat szintén értelmezésről szól (Auslegung). A vélemény 131. pontjának magyar fordítása ugyanerre a bekezdésre hivatkozva ugyancsak értelmezésre utal. E szerint az Európai Bíróság megköveteli, hogy a bíróságokra és hatóságokra nem lehet kötelező „a belső joguknak az említett Fórum által adott értelmezés”. Mindez tekinthető annak elismerésének is, hogy előfordulhat, hogy a CETA Fórum és Fellebbviteli Fórum mégiscsak értelmezhetik az uniós jogot. Márpedig az Achmea-ítéletben már annak lehetősége is elegendő volt ahhoz, hogy az Európai Bíróság megállapítsa az uniós jogrend autonómiájának sérelmét, hogy az uniós bírósági rendszeren kívül kerülhet sor az uniós jognak nemcsak az alkalmazására, hanem akár értelmezésére is.

Nem zárja ki semmi azt, hogy a CETA Fórum vagy Fellebbviteli Fórum olyan döntést hozzon, amely ellentétben áll az uniós joggal. ${ }^{18}$ A CETA Fórum ítélete elvben csak a vitában részt vevő felekre nézve és az adott ügy vonatkozásában kötelezö. ${ }^{19}$ Még ha ez a döntés az uniós jog értelmezése és alkalmazása tekintetében nem is köti sem az Uniót, sem a tagállamokat, a következménye az, hogy az Uniónak vagy valamelyik tagállamának kártérítést kell fizetni egy olyan döntés eredményeképpen, amely egyébként ellentétben áll az uniós joggal. Ez felveti a CETA Fórum döntése esetében, hogy az uniós joggal ellentétben álló döntés végrehajtható-e az Unió területén. ${ }^{20}$ A CETA 8.41 cikk (2) bekezdése értelmében a vitában részt vevő felek késedelem nélkül elfogadják az ítéletet és teljesítik az abban foglaltakat. Az, hogy az ítéletek végrehajtása szempontjából a CETA szerint az ítélet a New York-i Egyezmény, ${ }^{21}$ illetve az ICSID-egyezmény szerinti határozatnak minősül, szükre szabja az ítélet elismerése és végrehajtása megtagadásának lehetőségét is, ${ }^{22}$ jóllehet

${ }^{17}$ Gatti [2019], 117. o.

${ }_{18}^{18}$ Nanteuil [2019], 433. o.

${ }^{19}$ CETA 8.41 cikk.

${ }^{20}$ Nanteuil [2019], 433. o.

${ }^{21}$ 1962. évi 25. törvényerejü rendelet a külföldi választottbírósági határozatok elismeréséről és végrehajtásáról szóló, New Yorkban 1958. június 10-én kelt Egyezmény kihirdetéséről.

22 Ankersmit [2017] 27. o. 
hozzáteszi azt is, hogy az ítélet végrehajtására azon terület joga szerinti hatályos végrehajtási szabályok vonatkoznak, ahol az ítélet végrehajtandó, ami esetleg felvetheti az elismerés és végrehajtás megtagadását például a közrend védelmére hivatkozva. Az uniós jog elsőbbségéből fakadóan a tagállamokban az uniós joggal ellentétes határozatok nem hajthatók végre. Elképzelhető ugyanakkor az is, hogy a végrehajtást nem az Unió valamelyik tagállamában kérik, hanem egy harmadik államban. A CETA rendelkezései nem kötik harmadik országokat és egyáltalán nem szükségszerü az sem, hogy figyelembe veszik az uniós jogot, amikor az ítélet elismeréséről és végrehajtásáról döntenek. ${ }^{23}$ Ezek a problémák nem szakíthatók el az uniós jog autonómiájának kérdésétől.

Az Európai Bíróság által vizsgált másik kritérium az uniós jog alkalmazásának és értelmezésének kizártsága mellett az volt, hogy a vitarendezési rendszer ne gátolja meg az uniós intézményeket abban, hogy az Unió alkotmányos keretének megfelelően müködhessenek, valamint a felek demokratikusan meghozott, valamely beruházást esetlegesen érintő, közérdeken alapuló döntéseit. Ezzel kapcsolatban az Európai Bíróság kimondta, hogy a CETA fórumok nem vonhatják kétségbe az Unió által meghatározott közérdeket. Ez azt jelenthetné, hogy az Unió és tagállamai által meghatározott védelmi szintet egyáltalán nem lehetne megkérdőjelezni a nemzetközi jog alapján. ${ }^{24}$ Az Európai Uniónak az Emberi Jogok Európai Egyezményéhez csatlakozása esetén az Emberi Jogok Európai Bírósága éppen ezt tehetné. ${ }^{25}$ Jóllehet a CETA nem zárja ki a befektetéseket érintő intézkedések bevezetését az uniós jogban is elismert indokolt esetekben, azok csak annyiban alkalmazhatók, amennyiben például a tisztességes és méltányos elbánás követelménye szempontjából nem önkényesek, ${ }^{26}$ ami mégiscsak felülvizsgálati lehetőséget ad a CETA Fórumnak és Fellebbviteli Fórumnak. Nem kizárt tehát, hogy a tagállami vagy uniós jogon alapuló valamilyen terhet, például adót, a befektető a CETA Fórum előtt támadjon meg és a CETA fórumok eltérjenek az uniós jog felfogásától például az intézkedés szükségességének vagy önkényességének eltérő megítélése következtében. ${ }^{27}$ Amennyiben a CETA Fórum eltérően ítélné meg a CETA-ban és az uniós jogban elfogadott sztenderdeket, és ez az Unió vagy a tagállam marasztalásához vezetne,

23 Általában beruházási viták rendezésével foglalkozó bíróságok, ideértve a CETA Fórum, határozatainak elismeréséről és végrehajtásáról harmadik államokban, lásd: Káposznyák [2018], 553-562. o.

${ }^{24}$ Holterhus [2019].

${ }^{25}$ Holterhus [2019].

${ }^{26}$ CETA 8.10 cikk (2) bekezdés c) pont.

${ }^{27}$ Lásd: Ankersmit [2016], 57. o. 
az mégiscsak befolyásolhatja a közérdek védelmének szintjét az Unióban vagy a tagállamokban, és fennáll a kockázata, hogy az közvetett módon, a kártérítés hatására csökkenjen.

Az Európai Bíróságnak az uniós jogrendszer autonómiájára vonatkozó érvei tehát nem mindenben meggyőzőek. A fentebb felvetett kérdések és az azokra a CETA fórumok által adott válaszok rendkívül fontosak lesznek, mivel az Európai Bíróság pozitív véleményének köszönhetően a CETA egyfajta modellként szolgál majd az EU által a jövőben kötendő beruházási szabályokat is tartalmazó kereskedelmi egyezmények, valamint a tervezett multilaterális beruházási bíróság kialakítása számára.

\section{A vélemény jelentősége és a beruházásvédelmi bíráskodás jövője}

Mivel a CETA vegyes nemzetközi szerződés, annak részes felei Kanada mellett úgy az EU, mint a tagállamok, ezért hatálybalépéséhez szükséges az egyezmény ratifikációja a tagállamokban. Mivel a vélemény eloszlatja a kételyeket az uniós joggal való összeegyeztethetőség tekintetében, nem szükséges az egyezmény újratárgyalása Kanadával, és nincsen jogi természetủ akadály a CETA ratifikációja előttt. Az Európai Bíróság negatív döntése azzal a valószínű következménnyel járt volna, hogy beruházásvédelmi vitarendezési mechanizmusra vonatkozó szabályokat ki kellett volna venni a CETA-ból, illetve az Unió más kereskedelmi megállapodásainak sem képezhette volna részét. A CETA-vélemény így megerősíti más államokkal kötött egyezményben foglalt, hasonló vitarendezési eljárásokat, mint például éppen az Európai Bíróság véleményének kiadását két hónappal követően aláírt, az EU és Vietnám között létrejött beruházásvédelmi egyezmény szabályait.

A hagyományos beruházásvédelmi választottbírósági eljárások felváltása iránt az EU részéről tett lényeges lépés a CETA-ban foglalt vitarendezési mechanizmus bevezetése az uniós és a kanadai befektetők által kezdeményezett jogviták feloldására. További hatása a véleménynek az lehet, hogy a harmadik államokkal való kapcsolatokban az Unió által kereskedelmi megállapodásokban beruházási jogviták rendezésére létrehozott bíróságok fokozatosan felválthatják a hagyományos választottbírósági eljárásokat. ${ }^{28}$

${ }^{28}$ Nanteuil [2019], 436. o. 
Az Európai Bíróság véleménye azért is jelentős, mivel a vélemény egyben jelzi egy multilaterális beruházásvédelmi bíróság elfogadhatóságát is. Az utóbbi években a Bizottság többször sürgette multilaterális beruházásvédelmi vitarendezési mechanizmus kialakítását. A Tanács 2018-ban tárgyalási irányelvek meghatározása mellett felhatalmazta a Bizottságot, hogy az Unió nevében kezdjen tárgyalásokat az Egyesült Nemzetek Szervezetének Nemzetközi Kereskedelmi Jogi Bizottsága (UNCITRAL) keretében egy beruházási jogviták rendezésére hivatott multilaterális bíróság létrehozására. ${ }^{29} \mathrm{Az}$ irányelvek szerint az EU, illetve a tagállamok harmadik államokkal kötött megállapodásaira terjedne ki a multilaterális bíróság joghatósága, amennyiben a felek ennek alávetik magukat. A CETA megoldásához hasonlóan a bíróság egy elsőfokú és egy fellebbviteli fórumból állna. A multilaterális keret felváltaná az eddig a beruházásvédelmi választottbíráskodáson alapuló vitarendezést. Ennek megfelelően az UNCITRAL keretei között, a befektető és az állam közötti vitarendezés reformjáról szóló tárgyalások során ${ }^{30}$ az EU egy állandó, multilaterális beruházási bíróság létrejöttét javasolta. ${ }^{31}$ Mivel az Unió fontos szereplője ezeknek a tárgyalásoknak, a CETA-vélemény igen fontos lépés a beruházásvédelmi bíráskodás jövője szempontjából. A CETA-vélemény az uniós jog szempontjából ugyanis megnyitja az utat a multilaterális beruházásvédelmi bírósági fórum létrehozása előtt is. Az Európai Bíróság véleményében leszögezte, hogy az uniós joggal nem ellentétes az, hogy a CETA egy multilaterális igazságszolgáltatási fórum létrehozásáról rendelkezik. ${ }^{32}$ Ahogy a CETA vitarendezési mechanizmusa esetében ez történt, úgy egy jövőben létrehozandó multilaterális fórumnak - a CETA mintájára - szűkre kell szabni a hatáskörét: nem alkalmazhatja és értelmezheti az uniós jogot, nem állapíthatja meg valamely intézkedés jogszerüségét az uniós jog szempontjából, a multilaterális fórum uniós jogra vonatkozó értelmezése nem lehet kötelező az

29 Council of the European Union, Negotiating directives for a Convention establishing a multilateral court for the settlement of investment disputes, Brussels, 20 March 2018,

Letöltés: http://data.consilium.europa.eu/doc/document/ST-12981-2017-ADD-1-DCL-1/en/pdf.

Council of the European Union, Press release - Multilateral investment court: Council gives mandate to the Commission to open negotiations, 20 March 2018, Letöltés: https:/www.consilium.europa. eu/en/press/press-releases/2018/03/20/multilateral-investment-court-council-gives-mandate-tothe-commission-to-open-negotiations/.

30 United Nations Commission on International Trade Law Working Group III (Investor-State Dispute Settlement Reform), Possible reform of investor-State dispute settlement (ISDS), 5 September 2018, A/CN.9/WG.III/WP.149. Letöltés: https:/undocs.org/A/CN.9/WG.III/WP.149.

31 Submission of the European Union and its Member States to UNCITRAL Working Group III 18 January 2019,

Establishing a standing mechanism for the settlement of international investment disputes. Letöltés: https://trade.ec.europa.eu/doclib/docs/2019/january/tradoc_157632.pdf

32 1/17. sz. vélemény, 118. pont. 
Európai Bíróságra vagy a tagállami bíróságokra és hatóságokra. Természetesen egy multilaterális rezsim kialakítása túlmutat az Európai Unión. A multilaterális beruházásvédelmi bírósági mechanizmus létrehozásához nem elégséges pusztán az, hogy az az uniós joggal kompatibilis. Szükséges az is, hogy harmadik államok elfogadják az Európai Bíróság véleményében foglaltakat.

\section{Irodalomjegyzék}

Ankersmit, L. [2017]: Judging international dispute settlement: from the Investment Court System to the Aarhus Convention's Compliance Committee. Amsterdam Law School Legal Studies Research Paper, No. 2017-46., 1-28. o. Letölthető: https://papers.ssrn.com/sol3/papers.cfm?abstract $\mathrm{id}=3080988$.

Ankersmit, L. [2016]: Belgium Requests an Opinion on Investment Court System in CETA. Environmental Law Network International Review, 2. sz., 54-57. o.

Gatti, M. [2019]: Opinion 1/17 in Light of Achmea: Chronicle of an Opinion Foretold? European Papers, 4. évf., 1. sz., 109-121. o.

Holterhus, T. P. [2019]: Das CETA-Gutachten des EuGH-Neue Maßstäbe allerorten... verfassungsblog. de, 2019. május 3. Letölthetö: https://verfassungsblog.de/das-ceta-gutachten-des-eugh-neuemassstaebe-allerorten/.

Horváthy Balázs [2016]: A transzatlanti kereskedelmi tárgyalások és a beruházási vitarendezés reformja. In: Glavanits Judit - Horváthy Balázs - Knapp László (szerk.): Az európai jog és a nemzetközi magánjog aktuális kérdései - Ünnepi tanulmányok a 65 éves Milassin László tiszteletére. Széchenyi István Egyetem Deák Ferenc Állam- és Jogtudományi Kar Nemzetközi Köz- és Magánjogi Tanszék, Győr, 83-97. o.

Káposznyák Aliz [2018]: Beruházásvédelmi bírósági rendszer és a multilaterális beruházásvédelmi bíróság. Az általuk hozott határozatok elismerése és végrehajtása harmadik országokban. Jogi Tanulmányok, 2018, 553-562. o.

Nanteuil, de A. [2019]: Un tribunal permanent en matière d'investissement compatible avec le droit de l'UE. International Business Law Journal, 4. sz., 431-436. o.

Szabados Tamás [2015]: 'Precedents' in EU law - The problem of overruling. ELTE Law Journal, 2015. évf., 1. sz., 125-146. o.

Szabados Tamás [2019]: Az Európai Unió Bíróságának Achmea-döntése. Jogesetek Magyarázata, X. évf., 1. sz., 29-36. o. 